\title{
The Impact of Working Remotely from Home on Employee Performance During COVID-19 Pandemic: A Case of Batam City, Indonesia
}

\author{
Nia Fitria*, Qingmei Tan \\ Nanjing University of Aeronautics and Astronautics, P.R. China \\ *Corresponding author. Email: niafytria@ymail.com
}

\begin{abstract}
Many workers, both in government and private companies in Batam City, Indonesia, are required to Working from Home as recommended by the government to comply with the established protocol. This research has followed the methodology from Agus Purwanto (2020) and uses the productivity of Working from Home as benchmarks. It aims to identify and obtain information on the advantages and disadvantages of Working from Home (WFH) during the COVID19 Pandemic. Researchers used quantitative research, in-depth data analysis in numerical form. The questionnaire was distributed in the form of online support by Google form and received 102 respondents. The study results were that time flexibility, and relationship harmed work productivity while at home. However, the cost and relationship have a positive impact on work productivity. The more costs incurred for transportation, the higher the stress level of workers. This study found that relationships with family and colleagues also influence productivity. Virtual communication often causes miscommunication, so that work is inefficient at home.
\end{abstract}

Keywords: time flexibility, cost, relationship, working productivity.

\section{INTRODUCTION}

Novel Coronavirus 2019 (COVID-19) is an infectious disease caused by SARS-CoV-2, a coronavirus. Pneumonia caused by this virus that inflammation in the lung tissue causes interference with oxygen exchange resulting in breathing becomes congested. Patients with coronavirus can experience a dry cough, fever, and difficulty breathing. COVID-19 has spread to extremely fast from one to another. Coronavirus first being identified in Wuhan, Hubei Province, China, in December 2019. China was able to combat and contain the COVID-19 to a stable manageable level by resorting to severe measures that include different tasks, the highlights of which are: declaration of a state of emergency, total isolation of cities and provinces, lockdowns, massive disinfection campaigns, identification of genetic sequence for COVID-19, etc. Meanwhile, COVID-19 was first confirmed in Indonesia on March 2, 2020, and as of April 30, 2021 cumulatively, there have been $1.66 \mathrm{M}$ positive confirmed cases (cumulatively), of which 45.334 death, $1.52 \mathrm{M}$ recovered [20]. COVID-19 transmission from human to human has confirmed, and human mobility is also a reinforcing factor for the spread of COVID-19; information needed in this case, which would be useful to see the spread rate of COVIS-19 at an early stage. In the Riau Archipelago Province, Batam City cases infected around 7,174, or 0.6 percent of Indonesia's total cases. A more troubling crisis looms due to a reduction of economic curve hence affected many segments. The coronavirus cases increase day by day. In the middle of April, the Indonesian government issued a large-scale social restrictions status and a massive impact on the national economic curve. Many businesses are slowly bankrupt, and the condition of the small population is miserable. As we inability predict when the vaccine will found, by the middle of May, the Indonesia government slowly re-opening the line by re-starting all national activity as open the shopping mall, transportations, businesses to become normal with some protocols arranged by governments gradually.

In Indonesia, particularly in Batam City, Indonesia, Working from Home has not yet become a work culture in the government, corporate, and organizational segments. There are still few who have adapted WFH, but since the COVID-19 Pandemic, many companies have finally offered their employees to Work from Home at 
the government's appeal. Advances in technology make it easier to communicate and in the era of the current industrial revolution, more or less changed the work order in the organization [1]. Today's technology has changed attitudes and social life in society. Gender differences are no longer a limitation of qualifications and specifications in many jobs that no longer look at gender but more on human resources skills and knowledge. As a result, many companies are implementing work from home schemes. The scheme of Working from Home is nothing new in the world of work. There are various schemes in Working from Home, flexible schedule, and telecommunicating. According to [2], a flexible schedule makes it possible to balance work and personal life. Working from Home can make driving more flexible than working at the office all day.

The implementation of WFH in Indonesia to reduce the impact of being infected with COVID-19 and decision-making was implemented to maintain employee productivity. Besides reducing costs and transportation time taken from home to work, so it assumes that the Working from Home program also benefits workers. [3] Working From Home has not fully understood the dynamics of the company. They feel many dilemma conditions, where the mindset of Home is a place to rest while working should be in the office. This condition creates conflict in the family, even though working from Home is more flexible in place and time [4]. Therefore, this study aims to see the impact of Working from Home during Pandemic COVID-19 on costs, time effectiveness, work productivity, and family relationships.

\section{LITERATURE REVIEW}

The crisis caused by COVID-19 continued and locked down in many markets, posing challenges into unparalleled people and economies worldwide. Governments are beginning to arrange unpredicted economic support to adjust with businesses and workers. Nevertheless, many companies from all sectors struggle to survive, causing a massive number of people to lose their job and face deliberate financial uncertainty. This pandemic predicted had an impact for years to come, and one thing is sure, the crisis happen in the world of work is never going to be the same. The effect of the economic curve has a downturn and the ability of peoples to earn a living. The labor market and all stakeholders, including governments, must quickly accommodate this new reality, known as a new normal system where physical distancing and other strict requirements will be an integral part of all enterprise processes for extensive time to come. This includes a clear path, at least for workers.

According to [5], the shift to remote work caused by the Pandemic studied that Working from Home affects worker productivity in Baidu during the epidemic. [6] said that telecommunications could increase productivity at work. Working from Home, many employees feel a balance in carrying out their social life and work. One of them is communicating regularly with family even though it can only be done virtually. For female workers, dividing time for their families and cleaning the house can be done quickly. According to [7], it proves that WFH can balance the division of household tasks and improve family harmony. [8] connect what work can be done at home and work details. Besides, [9] adapted O*NET data to calculate physical closeness to the workplace's occupational levels. See which jobs cannot be done at home or will influence if they are in social distance [10]. Based on research from[11], there is negative correlation for some workers who have to work at home, and even many who lost their jobs during the COVID-19 Pandemic. Many companies are adapting WFH as a short-term plan, and it is predicted that it cannot be for the long term. [12] in their geographically distributed literature looks at what jobs can measure the eligibility of Working from Home. According to [13], the mobility system is our continuation due to climate change, including reducing carbon emissions. The impact of WFH, which previously never became popular but is now due to government protocols, has become popular. By the spring of 2020, this "taboo" had suddenly been broken, allowing for a broader social and political debate about the role of mobility and offered researchers the opport- uneity to study what a less mobile society looks like [14].

\section{THEORETICAL FRAMEWORK AND HYPOTHESIS}

Several studies have also discussed the impact of remote work. [11] show that workers in alternative work settings and in jobs where only a small part of the work can do from home are more likely to reduce their working hours, lose their jobs and suffer reduced income due to the coronavirus pandemic. More than $80 \%$ of the world's population is locked down (ILO, 2020), regulating work restrictions and making work from home protocols are also considered to affect workers' performance. And also covered by only a few who work in earnest while at home. [15] mentioned in their study that more than a third of all jobs can potentially do from home. [16] added that work from Home has the potential to have long-term impacts in the future caused by the COVID-19 Pandemic.

Adam Equity Theory which developed Job Motivation Theory, was chosen as the theory for this research. Adams Equity Theory recognizes that subtle factors and variables influence employees' decisions and perceptions about their relationship with their jobs. This theory is based on the belief that employees become motivated at work as long as their input serves the output greater. This theory seeks to improve employee job satisfaction. [17] doing remote work is associated with organizational commitment, job satisfaction, and workrelated welfare. Many companies are unable to provide 
for the welfare of their employees and end up terminating employment. [18] show that WFH is generally associated with lower net influence levels and unpleasant feelings than those who work in the workplace. However, this can vary depending on the type of remote work, with teleworking increasing individual stress. In this respect, this research is in line with [9]. The results provide important insight into the potential negative employment impacts arising from COVID-19 and contribute to discussions about how the Pandemic exacerbates inequality [11]. The variable used in this research is cost, time, and relation. From this current research, the author would like to know the impact of Working remotely from Home during Pandemic for the employee in Batam City, Indonesia.

\section{Hypothesis Development:}

H1: There is a significant negative between Cost to Work Productivity of Employee.

H2: There is a significant positive between Time Flexibility to Work Productivity of Employee.

H3: There is a significant positive between Relationship to Work Productivity of Employee.

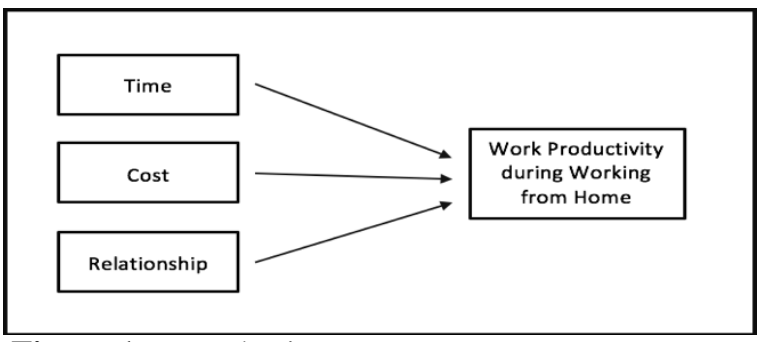

Figure 1. Hypothesis

\section{DATA COLLECTION}

An online survey with Google form conducted the study. Besides, to provide a brief representation of this study, the correspondent in this survey was shown to specify the impact of Working from Home on employee performance in the Batam City. And to recognize the employee's attitude in Batam City towards the cost, family, flexibility, and productivity. This research sample is 102 employees in the Batam City that ever enroll for Working from Home, with a percentage of 73.5 females and 26.6 males. Data used in this current research are from primary data using techniques of online questionnaire supported by Google form.

The questionnaire was develop based on previous research conducted by [19]. It emphasis eight items representing each aspect of this study. The online questionnaire was purposed and organized into the following section: demographic and employment status (not included in 8 main items of the question), work productivity as a dependent variable (two items). Whereas for independent variable consists of cost (two items), time flexibility (two items), and relationship (two items). The sampling used in this research was convenience sampling, where the sampling is an improbability method where the samples/correspondent are facile to access, by accessible location, and availability for a particular time.

\section{HYPOTHESIS AND RESEARCH MODEL}

\subsection{Descriptive Analysis}

This study has been mention earlier, will use a respondent in total 102 obtained by expanding the online questionnaire to employees in Batam City, Indonesia. Based on 102 online questionnaires distributed, there is no defective questionnaire. The whole process of collecting the data took two weeks and began in March 2021.

In the process, the researcher distributed the questionnaire online. In total, 27 people of male respondents $(26.5 \%)$ and female respondents in 75 people $(73.5 \%)$.

\subsection{Validity and Reliability}

Eight items or eight questions asked on the questionnaire were all declared valid. Because the Pearson Correlation value of each item is greater than $\mathrm{R}$ table 5\% in 102 respondents, and the significance value is not more than 0.05 . So through the validity test, the questions were declared valid. This research uses to analyze each variable from time, cost, relationship, and work productivity while Working from Home. The description of the data used in this study can be seen below.

Table 1. Validity Test

\begin{tabular}{|l|l|l|l|l|}
\hline $\begin{array}{l}\text { No } \\
\text { Ite } \\
\mathrm{m}\end{array}$ & $\begin{array}{l}\text { Pearson } \\
\text { Correlation }\end{array}$ & $\begin{array}{l}* \text { Table } \\
5 \% \\
(102)\end{array}$ & Sig & Criteria \\
\hline 1 & 0,279 & 0,195 & 0,005 & VALID \\
\hline 2 & 0,919 & 0,195 & 0,000 & VALID \\
\hline 3 & 0,830 & 0,195 & 0,000 & VALID \\
\hline 4 & 0,838 & 0,195 & 0,000 & VALID \\
\hline 5 & 0,736 & 0,195 & 0,000 & VALID \\
\hline 6 & 0,830 & 0,195 & 0,000 & VALID \\
\hline 7 & 0,636 & 0,195 & 0,000 & VALID \\
\hline 8 & 0,798 & 0,195 & 0,000 & VALID \\
\hline
\end{tabular}

Source: Processed by Primary Data (2021)

$\mathrm{R}$ Square is used to identify whether the independent can explain the dependent. And the data of this study can be seen: 
Table 2. Reliability Test

\begin{tabular}{|l|l|l|l|l|}
\hline Module & $\mathrm{R}$ & $\begin{array}{l}\mathrm{R} \\
\text { Square }\end{array}$ & $\begin{array}{l}\text { Adjusted } \\
\text { R Square }\end{array}$ & $\begin{array}{l}\text { Std. Error of } \\
\text { the estimate }\end{array}$ \\
\hline 1 & .719 & .517 & .503 & 1.06394 \\
\hline
\end{tabular}

Source: Processed by Primary Data (2021)

The table above indicates that the variable on each variable used in Cronbach's Alpha instrument is .616. This means, based on (Hair et al., 2010:92), the reliability description is Accepted and Reliable.

Table 3. Model Summary

Source: Processed by Primary Data (2021)

The table above indicates that the R Square is .719, which means that more than $71 \%$ of dependent variables

\begin{tabular}{|c|c|}
\hline \multicolumn{2}{|c|}{ Reliability Statistics } \\
\hline Cronbach's Alpha & N of Items \\
\hline .616 & 8 \\
\hline
\end{tabular}

can be used to explain the independent variable. And another $29 \%$ of the dependent variable is defined by an error term that is not included in this study.

\section{3. $t$-Test}

The t-test result, if it is under 0.05 , means each variable of independent influences the working productivity during Pandemic.

Table 4. t-Test Result

\begin{tabular}{|l|l|l|l|}
\hline $\begin{array}{l}\text { Variable } \\
\text { Independent }\end{array}$ & $\mathbf{T}$ & Sig. & Description \\
\hline $\begin{array}{l}\text { Time } \\
\text { Flexibility }\end{array}$ & -1.176 & .079 & $\begin{array}{l}\text { Significant } \\
\text { Negative }\end{array}$ \\
\hline Cost & 9.381 & .000 & $\begin{array}{l}\text { Significant } \\
\text { Positive }\end{array}$ \\
\hline Relationship & -4.914 & .001 & $\begin{array}{l}\text { Significant } \\
\text { Positive }\end{array}$ \\
\hline
\end{tabular}

Source: Processed by Primary Data (2021)

H1: Time Flexibility has Negative significant against Working Productivity during Pandemic COVID-19

The table above shows that the time flexibility has a significant negative value by using the t-test. The previous hypothesis states that the relationship between time flexibility produces a significant negative result in work productivity. Even if working remotely and working from home did not make work easy, the workload was a strong reason, according to the research questionnaire results. The comfort of being at home resulted in the work being done not optimally. This is undoubtedly a challenge in itself because it changes the concept of "office" as a place of work to "work from home." The results revealed that employees tend to postpone work and work longer because there is much outside interference.

H2: Cost has Positive significant against Working Productivity during Pandemic COVID-19

The table above shows that the cost has a significant positive value by using the t-test. The previous hypothesis states that the relationship between cost produces a significant positive result in work productivity. One of the advantages of working from home is the expense. That is, workers do not have to spend money to pay for transportation costs or gasoline costs. And that is followed by saving travel time. According to the research questionnaire results, prices positively affect worker productivity because it can save costs from all aspects. Not only transportation but also miscellaneous expense.

H3: Relationship has Positive significant against Working Productivity during Pandemic COVID-19

The table above shows that the relationship has a significant positive value by using the t-test. The previous hypothesis states that the relationship between relationships produces a significant positive result in work productivity. From the questionnaire, it stated that virtual communication had a very different psychological impact on employees, which causes communication and relationships hard to be smooth. Communication frequency should be done as often as possible to maintain the relationship. And continuously, communication with the family also does affect to work productivity.

\subsection{Normality Test}

Table 5. Test of Normality Kolmogorov-Smirnov

\begin{tabular}{|l|c|c|c|}
\hline & Statistics & $\mathrm{df}$ & Sig \\
\hline Productivity & .269 & 102 & .000 \\
\hline Time & .166 & 102 & .000 \\
\hline Cost & .220 & 102 & .000 \\
\hline Relationship & .199 & 102 & .000 \\
\hline
\end{tabular}

Source: Processed by Primary Data (2021)

1. The significance value of the Productivity variable (Y) on the Kolmogorov-Smirnov test is 0.269 ( $\mathrm{Y}>0.05$ ), so based on the normality test, the data is normally distributed.

2. The significance value of the Time variable (X1) in the Kolmogorov-Smirnov test is 0.166 ( $\mathrm{Y}>0.05)$, so based on the normality test, the data is normally distributed.

3. The significance value of the variable Cost (X2) in the Kolmogorov-Smirnov test is 0.220 (Y > $0.05)$, so that based on the normality test, the data is normally distributed. 
4. The significance value of the Relationship variable (X3) on the Kolmogorov-Smirnov test is 0.199 ( $\mathrm{Y}>0.05)$, so based on the normality test, the data is normally distributed.

\section{CONCLUSION}

To stop the spread of COVID-19, several countries, including Indonesia, have implemented a distribution protocol, starting with Working from Home. This policy's employment effect also varies and depends on the work eligibility to be carried out from home. Work from Home itself has advantages and disadvantages for employees. WFH can be done effectively if employees and companies both understand and understand work intensity. Time flexibility is one of the impacts of WFH itself. Initially, employees will feel the freedom to work when they are at home, but it also interferes with employee productivity due to external and internal factors. Then the cost of transportation also affects. The fewer transportation costs incurred, the employees can minimize the level of cost stress they experience. And work-life-balance employees balance between personal life and life at work. Employees can divide their time and balance it. However, a disadvantage that can also occur is the loss of motivation to work. Because maybe you do not have friends to discuss work problems, virtual communication is not effective enough, resulting in miscommunication. And it must be underlined that not all work can be done with the WFH concept.

Through the Work from Home (WFH) policy, the government is expected to make it easier for workers, especially in Batam City, Indonesia, to keep working even during the Pandemic that requires staying at home. Through this policy, employees assess that Working from Home will make it very easy for them, but this cannot be separated from the increasingly demanding work system. Nonetheless, there is still a need for rapid improvement, especially in the number of samples used in this study. These may not necessarily produce the same results for other provinces. And the accurateness of this research may be influenced by biases that affected privacy. And the r-square results mentioned almost $40 \%$ of the dependent variable could not be explained simultaneously in this study.

\section{AUTHORS' CONTRIBUTIONS}

Nia Fitria and Qingmei Tan. Conceived of the presented idea. Nia Fitria developed the theory and performed the computations. Qingmei Tan verified the analytical methods. Nia Fitria and Qingmei Tan discussed the results and contributed to the final manuscripts. Nia Fitria conceived the original idea. Qingmei Tan supervised the project. Nia Fitria conceived and planned the experiments. Qingmei Tan contributed to the interpretation of the result. Nia Fitria designed and performed the experiments, derived the models and analyzed the data. Qingmei Tan assisted with the test measurements and help on carry out the simulation. Nia Fitria and Qingmei Tan contributed to the design and implementation of the research, to the analysis of the result as and to the writing of the manuscripts.

\section{ACKNOWLEDGMENTS}

This research is supported by the National Social Science Foundation of China, number: 20\&ZD127. And thanks to Professor Qingmei TAN, Director Institute of Regional Economy \& Director Institute for Techoeconomics and Innovation Management, College of E\&M, Nanjing University of Aeronautics and Astronautics for the assistance that greatly improved our manuscripts.

\section{REFERENCES}

[1] Kumar, P. M. S., \& Aithal, P. S, Working From Home. A Transition in the Concept of Workplace. International Journal of Current Research and Modern Education (IJCRME), I(I), 2016, 244-249. DOI: https://doi.org/10.5281/zenodo.161110

[2] Mungkasa, Oswar, Bekerja Jarak Jauh (Telecommuting): Konsep, Penerapan dan Pembelajaran." Bappenas Working Papers. 2020, Vol. 3 No. 1. DOI: DOI:10.47266/bwp.v3i1.52

[3] de Vos, D., Meijers, E., \& van Ham, M, Working from home and the willingness to accept a longer commute. Annals of Regional Science ,61(2), 375398. DOI: https://doi.org/10.1007/s00168-0180873-6

[4] McCloskey, D. W, An examination of the boundary between work and home for knowledge workers. International Journal of Human Capital and Information Technology Professionals, 9(3), 2018, 25-41. DOI:10.4018/IJHCITP.2018070102

[5] Bao, L., Li, T., Xia, X., Zhu, K., Li, H., \& Yang, X, how does Working from Home Affect Developer Productivity? - A Case Study of Baidu During COVID-10 Pandemic." ACM Joint European Software Engineering Conference and Symposium on the Foundations of Software Engineering (ESEC/FSE). Sacramento, 2020.

[6] Kazekami, S, Mechanisms to improve labor productivity by performing telework. Telecommunications Policy, 2020. DOI: DOI:10.1016/j.telpol.2019.101868

[7] Dockery, A. M., \& Bawa, S, when two worlds collude: Working from home and family functioning in Australia. International Labour Review, 157(4), 2018, 609-630. DOI: http://dx.doi.org/10.20473/tijab.V4.I1.2020.13-21 
[8] Avdiu, Besart, and Gaurav Nayyar, when face-toface interactions become an occupational hazard: Jobs in the time of COVID-19. Brookings Future Development Blog, 2020.

[9] Mongey, Simon, and Alex Weinberg, Characteristics of Workers in Low Work-FromHome and High Personal Proximity Occupations. Becker Friedman Institute for Economic White Paper, 2020.

[10] Baker, Marissa G, characterizing occupations that c annot work from home: a means to identify suscept ible worker groups during the COVID-19 pandemi c. medRxiv, 2020. DOI: DOI:10.1101/2020.03.21.2 0031336

[11] Adams-Prassl, Abi, Teodora Boneva, Marta Golin, and Christopher Rauh, Inequality in the Impact of the Coronavirus Shock: Evidence from Real Time Surveys. IZA Discussion Paper 13183, $202 \mathrm{O}$.

[12] Hensvik, Lena, Thomas Le Barbanchon, and Roland Rathelot, Which Jobs Are Done from Home? Evidence from the American Time Use Survey. IZA Discussion Paper 13138, 2020.

[13] Ferreira, A., Bertolini, L., \& Næss, P, Immotility a $\mathrm{s}$ resilience? A key consideration for transport polic y and research. Applied Mobilities, 2(1), 2017. 16-3 1. DOI: https://doi.org/10.1080/23800127.2017.12 83121

[14] Nikolaeva, A., Adey, P., Cresswell, T., Lee, J. Y., Nóvoa, A., \& Temenos, C, Commoning mobility: Towards a new politics of mobility transitions. Tra nsactions of the Institute of British Geographers, 2 019, 44(2). DOI: https://doi.org/10.1111/tran.1228 7

[15] Dingel, J.; Neiman, B, How many jobs can be done at home?. Covid Economics: Vetted and real-time papers. No 1, pp. 16-24, 2020.

[16] Baert, S.; Lippens, L.; Moens, E.; Sterkens, P.; Weytjens, J, The Covid-19 crisis and telework: A research survey on experiences, expectations and hopes, IZA discussion paper; No 13229, 2020.

[17] Felstead, A. and Henseke, G, Assessing the growth of remote working and its consequences for effort, well-being and work-life balance, New Technology, Work and Employment, Vol. 32, No. 3, 2020, pp. 195-212. DOI: https://doi.org/10.1111/ntwe.12097

[18] Song, Y. and Gao, J, Does telework stress employees out? A study on working at home and subjective well-being for wage/salary workers, IZA Discussion Paper series, No. 11993, 2020.
[19] Agus Purwanto, Pengaruh Gaya Kepemimpinan Transaksional, Authentic Studi Eksplorasi Dampak Work From Home (WFH) Terhadap Kinerja Guru Selama Pandemi Covid-19. Journal of Education, Psychology and Counselling, 2020, Volume 2 No 1.

[20] Updates on coronavirus cases (COVID-19). World Health Organization. Updated: April 31, 2021. Ava ilable online: https://www.worldometers.info/coron avirus/

[21] World Bank. 2021 "World Development Indicators ". Retrieved from: https://datacatalog.worldbank.or $\mathrm{g} /$ dataset/world development-indication 